\title{
The Black Church Cemetery: Interdisciplinary Approaches to the Study of a Medieval Urban Skeletal Assemblage (Braşov, Romania)
}

\author{
DANIELA MARCU ISTRATE, Institutul de Arheologie "Vasile Pârvan", Romania \\ ANNAMARIA DIANA, The University of Edinburgh, UK
}

The aim of this paper is three-fold: 1) to present results of the archaeological excavations conducted in the area surrounding the Black Church in Braşov (Transylvania, Romania); 2) to show the outcome of the analysis of a small human skeletal sample; and 3) to stress the importance of biocultural interpretations of burial sites for a better understanding of the process of urbanization in southern Transylvania.

During the Middle Ages Braşov, founded in the 12th century by Central European colonists, was a flourishing multi-cultural and multi-ethnic urban community located in the heart of the Carpathian Mountains (Transylvania, Romania), and a busy crossroad for travelers, merchants and diplomats from Romania, other European countries and the Middle East. Between 2012 and 2013 a team of archaeologists conducted rescue excavations in the area surrounding the Black Church, unearthing a stratigraphically challenging complex of structures formed by centuries of uninterrupted human habitat, and over 1,400 graves in the medieval cemetery annexed to the church. The observation and interpretation of burial practices, grave goods and funerary topography, integrated with the demographic and pathological profile of human skeletal remains from 170 burials have shed new light on the life and death of the members of this middleclass population. In fact, bio-social and bio-cultural patterns were identified through the integration of multidisciplinary sources of evidence.

The team involved in the post-excavation processing of archaeological materials from the Black Church cemetery is keen to promote further investigations of the archaeological site presented here, which is of inestimable value for the reconstitution of the development of urban life in medieval and modern Eastern Europe, and to present the lesser-known, albeit no less interesting, Romanian cultural heritage to international scholars and to the general public.

Key words:

Medieval Transylvania; Funerary archaeology; Biocultural studies; Human osteoarchaeology; Paleopathology.

SDH Reference:

Daniela Marcu Istrate and Annamaria Diana 2017. The Black Church Cemetery: Interdisciplinary Approaches to the Study of a Medieval Urban Skeletan Assemblage (Braşov, Romania). SDH, 1, 2, 364-379.

DOI : $10.14434 /$ sdh.v1i2.23233

Authors' addresses: Dr Daniela Marcu Istrate, Senior Archaeologist, Institutul de Arheologie "Vasile Pârvan", Bucharest, Romania; email: damasus2000@yahoo.com; Dr Annamaria Diana, Human Osteoarchaeologist; email: omseti@hotmail.com Permission to make digital or hardcopies of part or all of this work is granted without fee according to the open access policy of SDH.

(C) 2017 SDH Open Access Journal

Studies in Digital Heritage, Vol. 1, No. 2, Publication date: December 2017 


\section{ARCHAEOLOGICAL ANALYSIS}

\subsection{Braşov: the origins}

The city of Brașov is located in central-western Romania, in Transylvania, a region which in the Middle Ages belonged to the Hungarian Kingdom. Transylvania was conquered gradually by the Hungarians during the 10th-11th century AD, and, by the 13th century, its territory was included in the political, administrative and religious structures of the kingdom.

A decisive role in the shaping of this region's societal and political organization was played by colonists. Settlers from central Europe (generally called Saxons) were enticed to settle in Transylvania by the promise of significant privileges [Nägler 1992; Crîngaci TTiplic 2011]. From the second half of the 12th century to the beginning of the 13th century, this process of colonization in south Transylvania led to the formation of a network of settlements [Niedermaier 2002; 2004]. Among them, the most important was Sibiu, which became the main religious, political and cultural center for the local German community, and one of the most relevant cities in Hungary [Marcu Istrate 2007]. Braşov (or Kronstadt in German) was the second biggest city, becoming at the end of the medieval ages the most populated and advanced commercial center in Transylvania [Roth 2010; Philippi 1996].

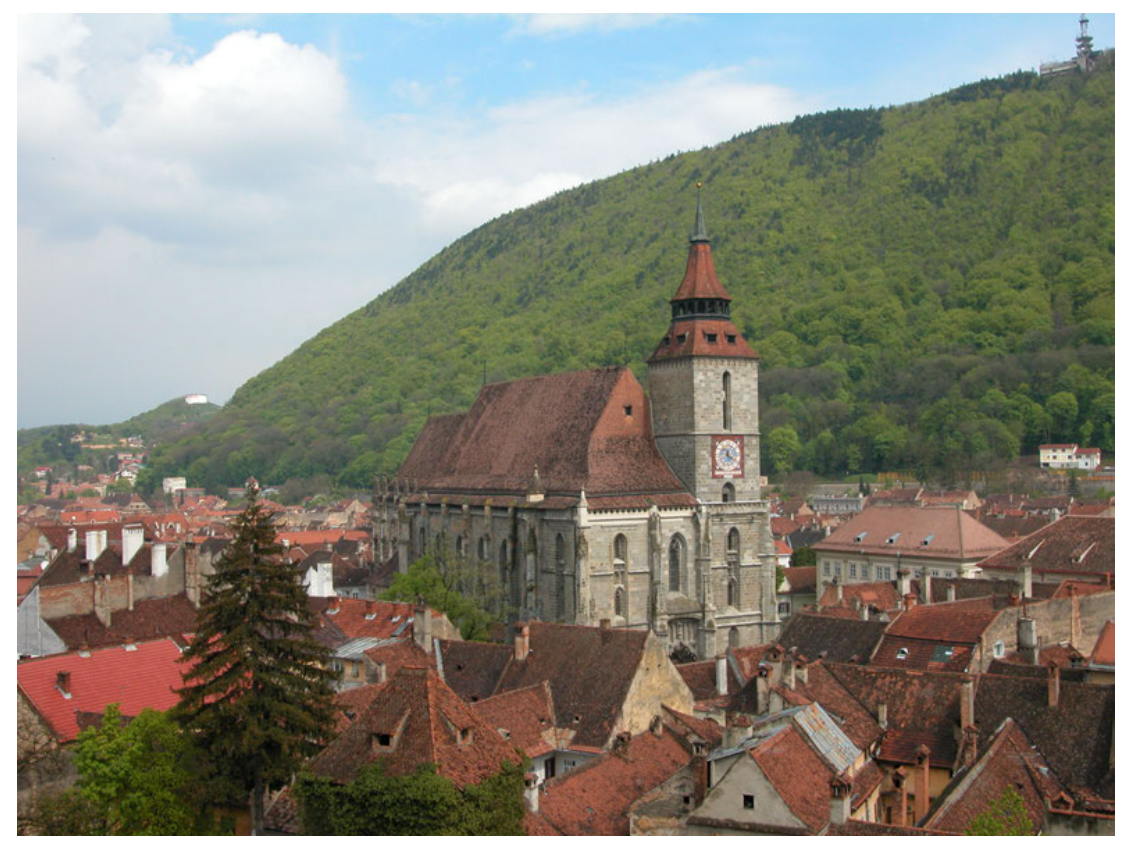

Figure 1. The Black Church today (photo: Daniela Marcu Istrate).

The settlement is mentioned for the first time in 1235, by the name Corona, as the location of a Premonstratensian monastery: "Claustra sororum ... in Hungaria ... Dyocesis Cumaniae Corona" [Philippi 1996]. This religious building's existence was short-lived, as it was destroyed by the Tartar invasion of 1241. In 1252, although not yet definable as a "city," Brașov/Kronstadt surely was the most 
developed and important settlement in the area, mentioned in the sources as the politicaladministrative center of the region. By the end of the 13th century, two further Tartar invasions devastated the settlement (in 1278 and 1285), and any economic and social advancement taking place at the beginning of the 14th century was once again halted by the invasion in the year 1345. Around the year 1370 construction began on a catholic parish church dedicated to Saint Mary. The building process lasted for over a century and produced the largest Gothic church in southeast Europe, greatly admired for its architectural and artistic value, and today known as the Black Church (figure 1) [Kühlbrandt 1928; Vătășianu 1959; Entz 1996 Nussbächer 2008; Bálint 2009].

Little to no written information has been preserved from the early period of this history. Local written sources are not very informative for the period up to the end of the 17th century, and were lost in the year 1689 following a devastating fire that almost entirely destroyed the historical center and the most important administrative buildings and churches. Furthermore, although accounts and diaries left by foreign travellers and diplomats of political, economic or cultural exchanges with the Transylvanian center [Murgescu 2001] can be significantly enlightening, such sources have to be taken with a grain of salt, especially when clearly subjective. Thus, archaeology remains the main source of information for the reconstruction of this long period in the history of the city, especially as regards its origins.

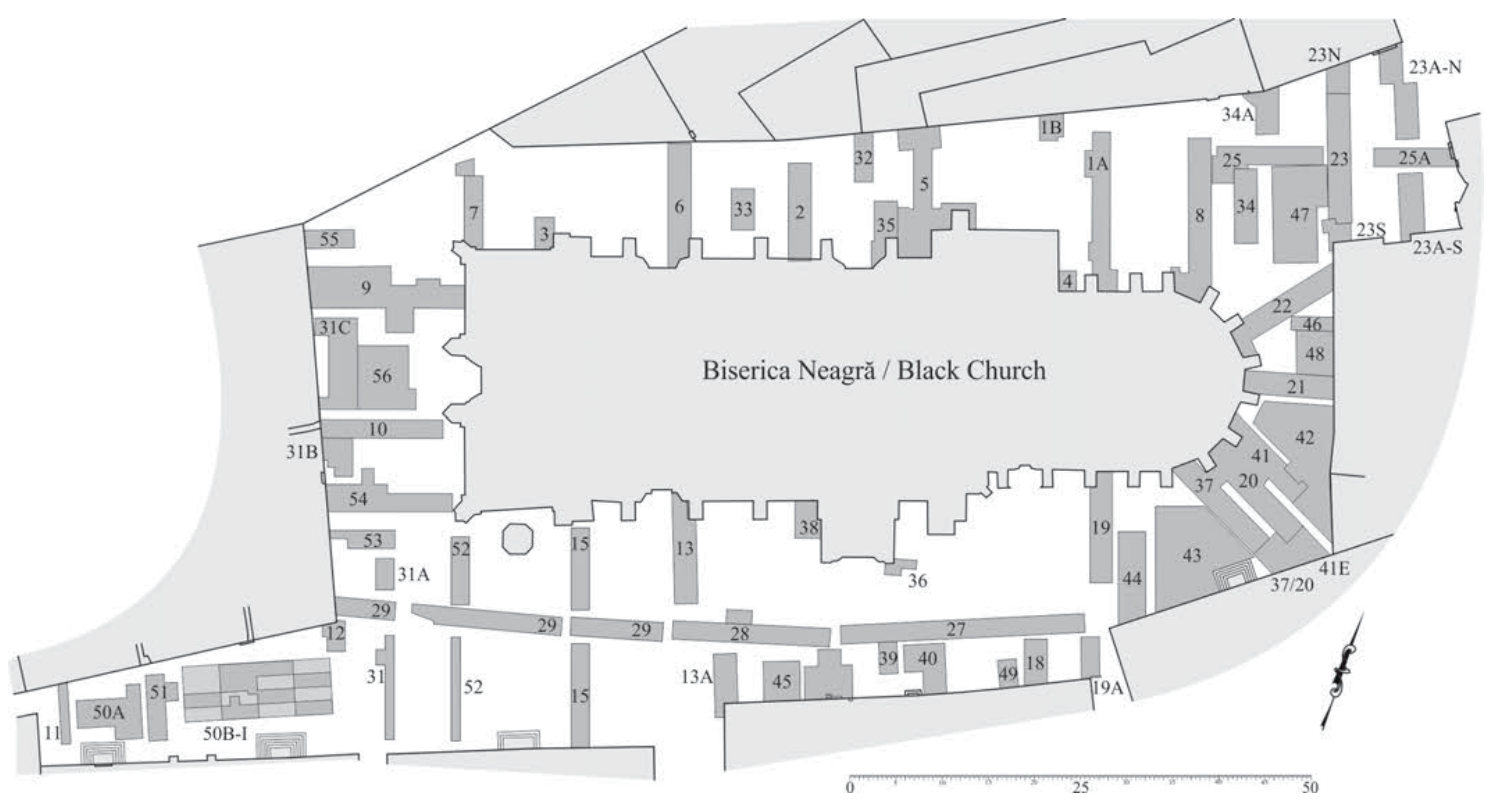

Figure 2. Plan showing trenches excavated around the Black Church.

\subsection{The city center rescue excavations}

Between 2012 and 2013, the historical core of the town, including the area of the parish Black Church, was archaeologically investigated before restoration work was initiated. The research was accomplished by digging narrow trenches and by the occasional excavation of variously shaped and 
sized open areas (figure 2). Although it would have been beneficial, large-scale surface research could not be conducted for several reasons, the foremost being the safety of the existing buildings and compliance with traffic regulations in the area.

Archaeologists unearthed an enormous amount of information and remains: traces of habitation (hearths, dwelling areas, pits, annexes, latrines, etc.), potsherds and objects made of metal, glass, stone and bone, fortified structures, and a cemetery.

The archaeological context has shown that the first dwellings, built with earth and wood around the year $1200 \mathrm{AD}$, were followed in the 13th century by constructions of stone and mortar, which occupied a larger area. Furthermore, while dwellings probably belonged to one of the western colonists' first settlements, stone buildings must have belonged to the monasteries successively mentioned in this area in 1235 (Premonstratensian) and in 1388 (Cistercian) [Marcu Istrate 2015]. As a result, data regarding the evolution of the church and other buildings, burial customs and the daily life of the inhabitants have been observed through the preliminary interpretation of archaeological contexts and finds.

\subsection{The Black Church cemetery}

The most important achievement of the rescue archaeological research presented in this paper was the opportunity to excavate a significant area of the parish graveyard, which is now the second largest medieval graveyard excavated in Transylvania.

The cemetery was established around $1200 \mathrm{AD}$ and remained in use long after the Reformation, until ca. 1800. While in the Middle Ages interments especially occurred in the northern area, in the modern period they were located in the southern and the northern areas, quite close to the neighboring houses. Even though in other Transylvanian towns cemeteries were moved outside the walls during the Reformation (in the middle/second half of the 16th century), the Black Church cemetery appeared to become even more crowded in the 17th and 18th centuries.

Given that the community continued to bury their dead in the same area over a period of several centuries, the churchyard slowly but inevitably became a deposit containing more human remains than earth. In fact, archaeological stratigraphy showed up to 6-7 layers of graves, and, especially north of the church, a density of 15 graves per square meter. Overall, more than 1,400 funerary features were registered and investigated.

\subsubsection{The stratigraphical and architectural context}

As mentioned above, the Black Church cemetery was a crowded urban cemetery located within a complex archaeological stratigraphy. Many burials cut through pre-existing structures, such as the walls of early masonry buildings, adobe and charcoal layers left behind by the earliest dwellings, and disturbed earlier graves, consequently destroying human skeletal remains and mixing the soil context. Moreover, quite a few graves were cut by the foundations of more recent masonry structures, especially by those of the parish church and its chapels, and of the parish houses and other associated buildings (figure 3). 


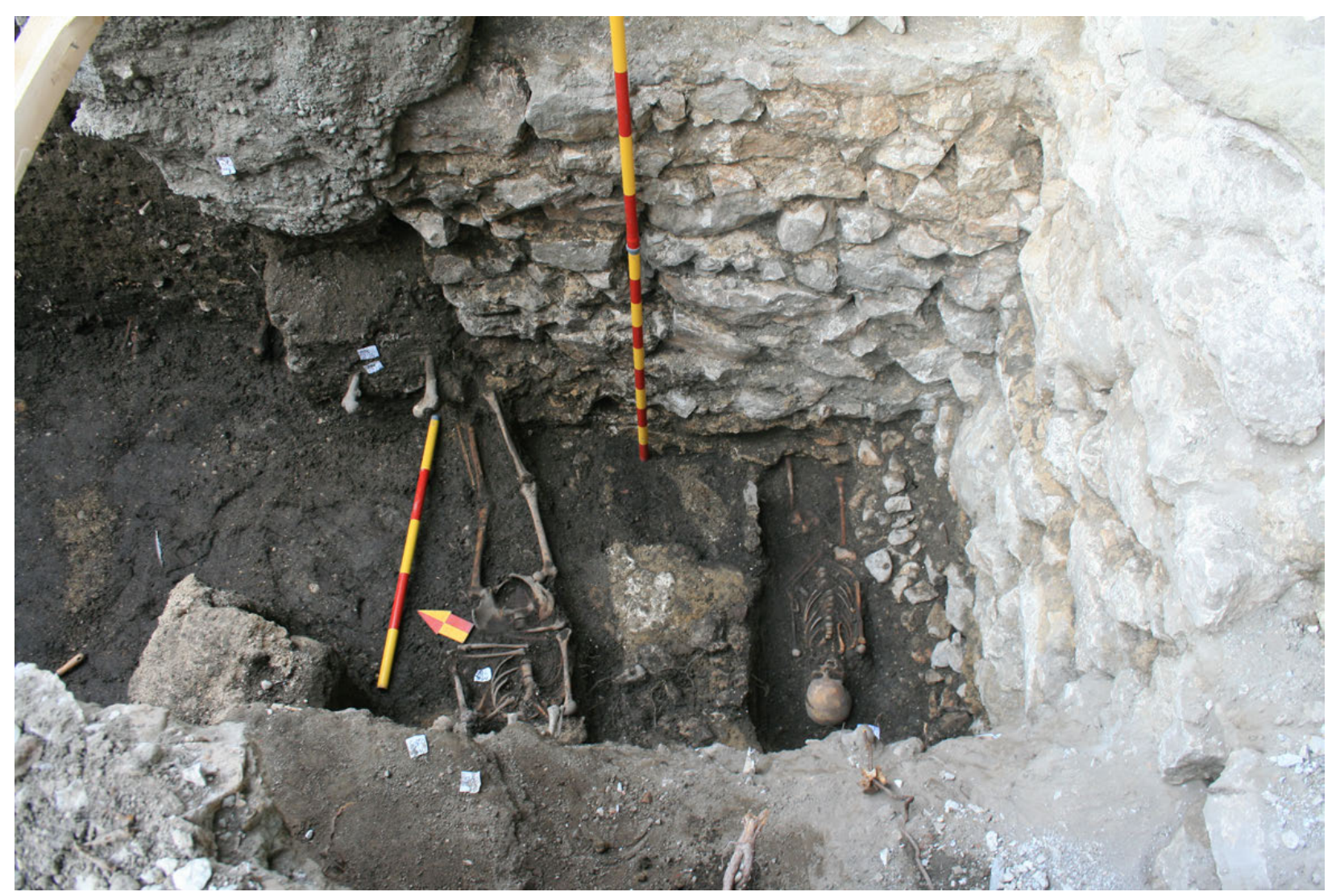

Figure 3. Medieval graves disturbed by the foundation of St. Mary's church (photo: Daniela Marcu Istrate).

The listed activities led to the disappearance of many graves-the only trace left of them is the impressive quantity of disarticulated bones found in pits and in the soil between the surviving graves. Considering the evolution of other medieval urban cemeteries, it is likely that only one-third of the burials (probably considerably less) could still be identified as such at the moment of our investigation. While the complications listed here greatly affected the excavation process, they also were key to the understanding and dating of the evolution of the site.

\subsubsection{Spatial distribution, burial ritual and chronology}

The majority of graves, represented mainly by individual burials, seemed to be randomly distributed over the entire surface, with a tendency towards overcrowding north of the parish church. Another characteristic was the presence of grave clusters - small areas where a large number of dead were buried at once or at different points in time (figure 4). While smaller grave clusters could be accidental, several large ones, south and west of the church, may have functioned as family graves. At the current stage of analysis, however, other reasons cannot be excluded. In addition to individual and multiple burials, pits with re-interred bones and ossuaries containing disturbed or intentionally exhumed bones were also exposed. 
The cemetery was delimited by a solid stone wall, with a thickness that may have exceeded $1 \mathrm{~m}$ : remnants of this wall, with several restoration stages showing slight changes to its extension, were identified in the eastern area of the square. In time, buildings took the place of this enclosure wall, and the funerary area became increasingly smaller and closer to the church. The funerary space was not organized, the placement of graves suggesting that it was used by the entire community as joint property.

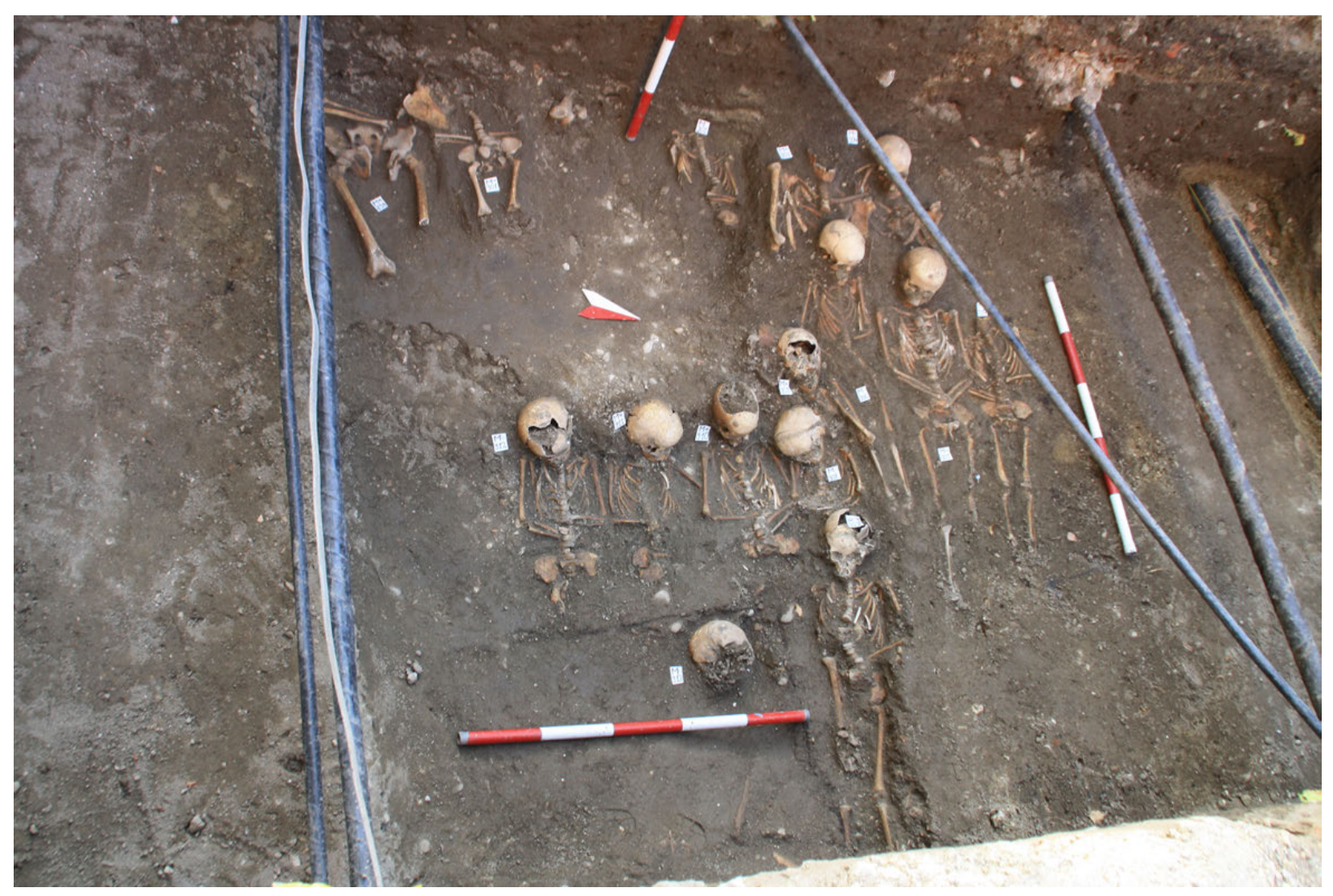

Figure 4. Area showing burial clusters (photo: Daniela Marcu Istrate).

Graves were dug in a sandy matrix, filled with stones, mortar and brick fragments, and numerous human bones. Several burial positions were identified [Marcu Istrate 2015]; dominant, however, was the custom of placing the deceased's forearms overlaying the body. Although the majority of individuals faced east, lying on their back, about a fifth of the graves had different orientations. The unusual orientation of the latter could be attributed to the fact that the medieval gravediggers used the wall of the church as a reference to establish where East and West were. Thus, behind the choir, where the church walls curved, so did the burials' orientation. Furthermore, a very small percent of graves (about 7\%) yielded inventory items, coins or clothing accessories. 
Two factors contributed to limiting the establishment of a chronology for the cemetery: 1) the uniformity concerning burial ritual and funerary inventory-as would have been expected for a medieval Christian cemetery, and consequently, 2) the fact that absolute chronology indicators (coins, relationship with dated structures) represented only $10-12 \%$ of dating elements. Thus, the identification of chronological sequences was attempted by combining the topographic method (based on the relations between the graves reflected in a Harris Matrix) with the analysis of the context and the relationship between graves, built structures and artefacts.

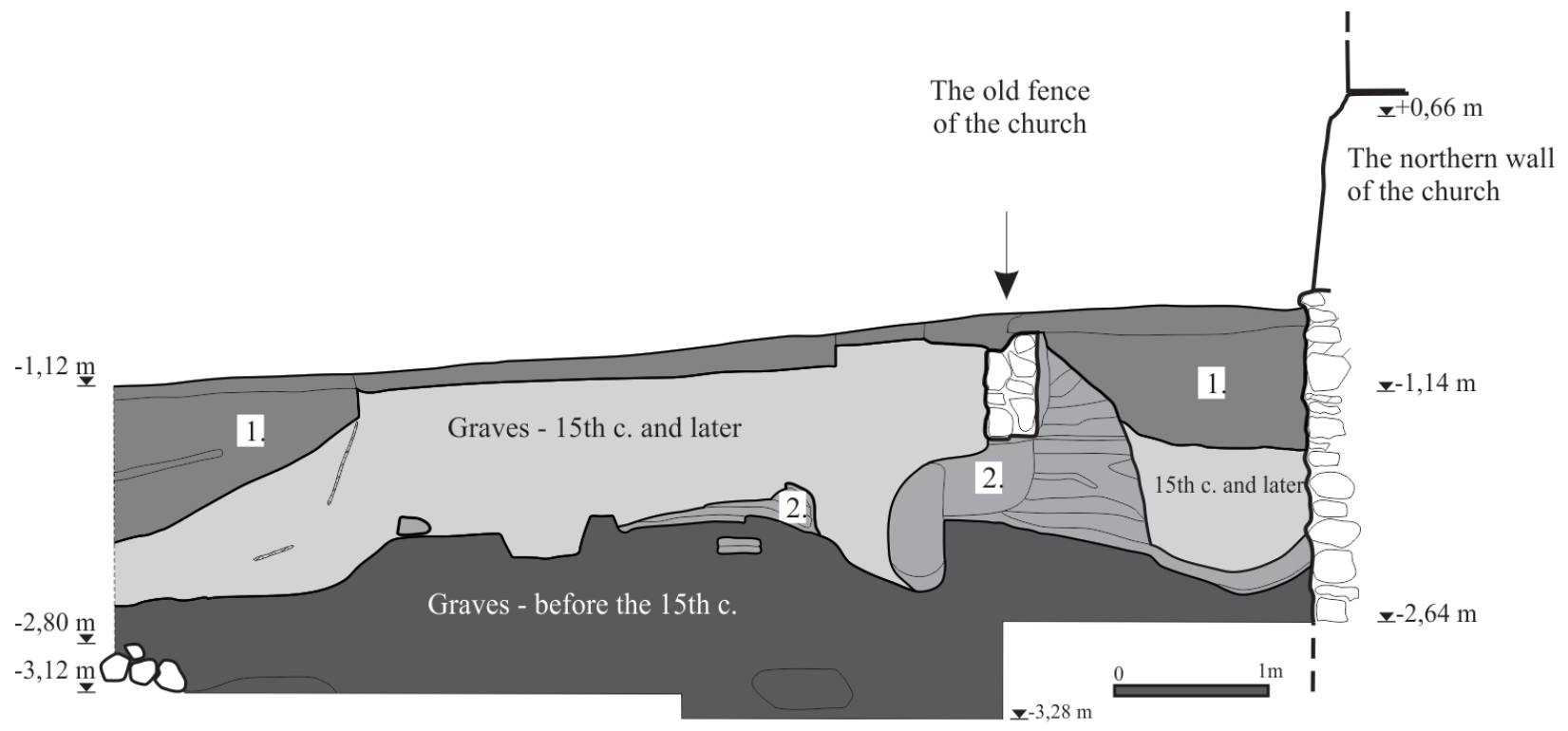

1. Various contemporary interventions

2. Various medieval and modern deposits

Figure 5. Burial layers on the northern side of the cemetery.

\subsubsection{Stages of use}

The topographic-chronological analysis allowed the identification of four main stages:

1) The early stage of habitation, between the end of the 12th century and the beginning of the 13th century, had burials mainly concentrated north of the area (figure 5). The most common backfill consisted of black soil or black soil mixed with yellow clay; the most often encountered skeletal position was the one with arms and forearms stretched next to the body.

2) The second stage was also concentrated on the northern part of the cemetery, associated with the monastic period, between 1250 and 1370. This level was characterized by pigmented backfills and remnants of earlier vestiges (adobe fragments, pottery and stones), although graves with very clean backfill were also identified here. The position of the arms showed several patterns but dominant was the one where the forearms were placed over the body. 
3) During the third stage (ca.1370-1542), beginning with the period when the Black Church was constructed, the area surrounding the religious building was entirely occupied by the parish cemetery.

4) After Reformation in 1542, the cemetery dwindled in size, retreating closer to the church and eventually being abandoned. The graves were dug in an extremely mixed deposit, containing a large quantity of debris and human bones. Many of the burials were oriented on a north to south axis. The dead were laid down with their arms bent at right angles and the forearms over the chest area.

From the later stages of use of the cemetery, tombstones were retrieved. On one of them the original inscription was scraped off and replaced with a new one: "ANO 1752 CSS." Another tombstone (grave M1213), discovered west of the church, displayed decoration consisting of two concentric circles and a cross, but once again the original inscription, located at the opposite end, was illegible.

Furthermore, coffin traces and remnants were often identified, especially at the level of the later upper layers. Most of the time, however, only barely visible traces of coffin wood and/or iron nails survived. Consequently, it would appear that about every sixth tomb had a coffin or other similar structure made of wood. Some of the coffins were painted, while others had engraved plates - one such metal plate mentions the name of Elisabeth, who passed away on 18 July 1783 [Marcu Istrate 2015].

Some of the later structures unearthed in this cemetery may have been crypts, the earliest dating back to the eighteenth century, built between the buttresses of the choir by closing up the space with brick walls. They were later decommissioned, the coffins exhumed (probably to be transferred into the church) and their interior was backfilled with rubble. This action may have taken place around 1800, after the 1788 ban on interments within the parish cemetery [Nussbächer 2008].

After these events, the yard of the cemetery became a public space, being landscaped for pedestrian use.

\section{OSTEOLOGICAL ANALYSIS}

\subsection{Materials and methods}

\subsubsection{Burial patterns and condition of the remains}

A minimum number of 206 individuals from 170 randomly sampled archaeological contexts were analyzed and identified on the documentation provided by the archaeologists. The identification of burial patterns for this group of graves was quite straightforward, given that the majority were individual and, occasionally, double burials. In fact, disarticulated and/or commingled remains were retrieved from only nine archaeological contexts. Furthermore, 1228 permanent teeth (still in situ or loose but clearly belonging to a specific individual), 33 permanent loose teeth, and 90 deciduous teeth were counted. 
The state of preservation of the remains-recorded by scores poor (0-25\%), fair (25-50\%), good (50-75\%) and excellent (75-100\%) - was generally good, given that more than $65 \%$ of skeletal remains presented a fair to excellent condition. This estimate was obtained by averaging two separate scoring codes, one for the condition of the bone itself (i.e. degree of taphonomic and post-depositional damage) and one for skeletal completeness (i.e. how many bones from a whole skeleton were represented).

\subsubsection{Analytical methods}

The osteological analysis was performed by one investigator and all assessments were carried out by visual inspection at the macroscopic level only, given time and funding constraints. For the assessment of age at death, sex and stature guidelines provided by general manuals [Buikstra and Ubelaker 1994; Hillson 2005; Bass 2005; White and Folkens 2005] and specialised articles were followed. Standard methods for the assessment of demographic features were used, keeping in mind the observed population's geographical and historical context of provenience (i.e., when possible, population-specific standards were preferred). Biological sex was assessed on adults by crossreferencing scores of the pelvic and skull morphology (as described by Walker [in Buikstra and Ubelaker 1994]) with indices and metric measurements' sectioning points [Bass 2005]. On adult individuals, age estimation was carried out by scoring the appearance of the pubic symphysis and the auricular surface of the ilium [Todd 1920; Brooks and Suchey 1990; Lovejoy et al. 1985; Buckberry and Chamberlain 2002], and of the sternal rib ends [İşcan et al. 1984]. The state of fusion of the medial clavicle [Black and Scheuer 1996] and of the sacral elements [Schaefer et al. 2009] and dental attrition [Brothwell 1989] were also scored. Juvenile (subadult) sex was not assessed, while age was estimated by observation and record of the epiphyseal stage of fusion, dental development and maximum length of diagnostic bones [Schaefer et al. 2009]. Adult stature was measured by applying regression equations by Trotter and Gleser 1952 to the maximum length of all preserved diagnostic long bones.

Pathological and anomalous lesions were recorded by detailed descriptions, photographs and measurements. Furthermore, their frequency (number of lesions) and prevalence (number of individuals affected at a specific point in time) were observed by skeletal location, sex, and age. Methodological and theoretical principles developed by Ortner 2003 and Waldron 2009 were mainly followed, together with the indications and case studies reported in other manuals [Aufderheide and Rodríguez-Martín 1998; Roberts and Manchester 2010] or articles from the palaeopathological, medical and forensic literature. Data was collected in databases created ad hoc, and coded in order to be statistically tested at a later stage and to allow flexibility when more data are introduced.

\subsection{Results}

\subsubsection{Age-at-death}

A total of 130 adults (63\%) and 76 juveniles (37\%) composed this population (figure 6). Only three foetuses and seven infants were identified (almost $5 \%$ of the total together), while eighteen children up to five years of age and thirty-four up to twelve years of age were also recorded (respectively $8.7 \%$ and $16.5 \%$ of the total). Adolescents were only represented by fourteen individuals (6.8\%). Furthermore, nineteen adult individuals younger than twenty-five and sixteen between twenty-five and twenty-nine years of age (respectively $9.2 \%$ and $7.8 \%$ of the total sample) were identified; one 
individual was aged between eighteen and twenty-nine years. Thirty-eight adults were aged between thirty and forty years, while only twelve were between forty and forty-five years of age (respectively $18.4 \%$ and $5.8 \%$ of the sample); two mature adults could only be aged between thirty and forty-five years. Finally, thirteen individuals were older than forty-five and only four might have been older than fifty-five years of age (6.3\% and $1.9 \%$ respectively). A total of twenty-five individuals could only be attributed to the adult category given the lack of specific aging elements.

\subsubsection{Biological sex}

The Black Church assemblage showed a higher number of males among individuals whose sex could be assessed (figure 6). In fact, there were a total of 68 males (of which $25.2 \%$ were classified as males with a good degree of certainty, while $7.7 \%$ were probably males) and 50 females (of which $17.5 \%$ were attributed to the female sex with certainty, while $6.8 \%$ had $50 \%$ to $75 \%$ of probability of being females). Finally, among the individuals whose sex could not be assessed, only sixteen (7.7\%) were adults and seventy-two (34.9\%) were children.

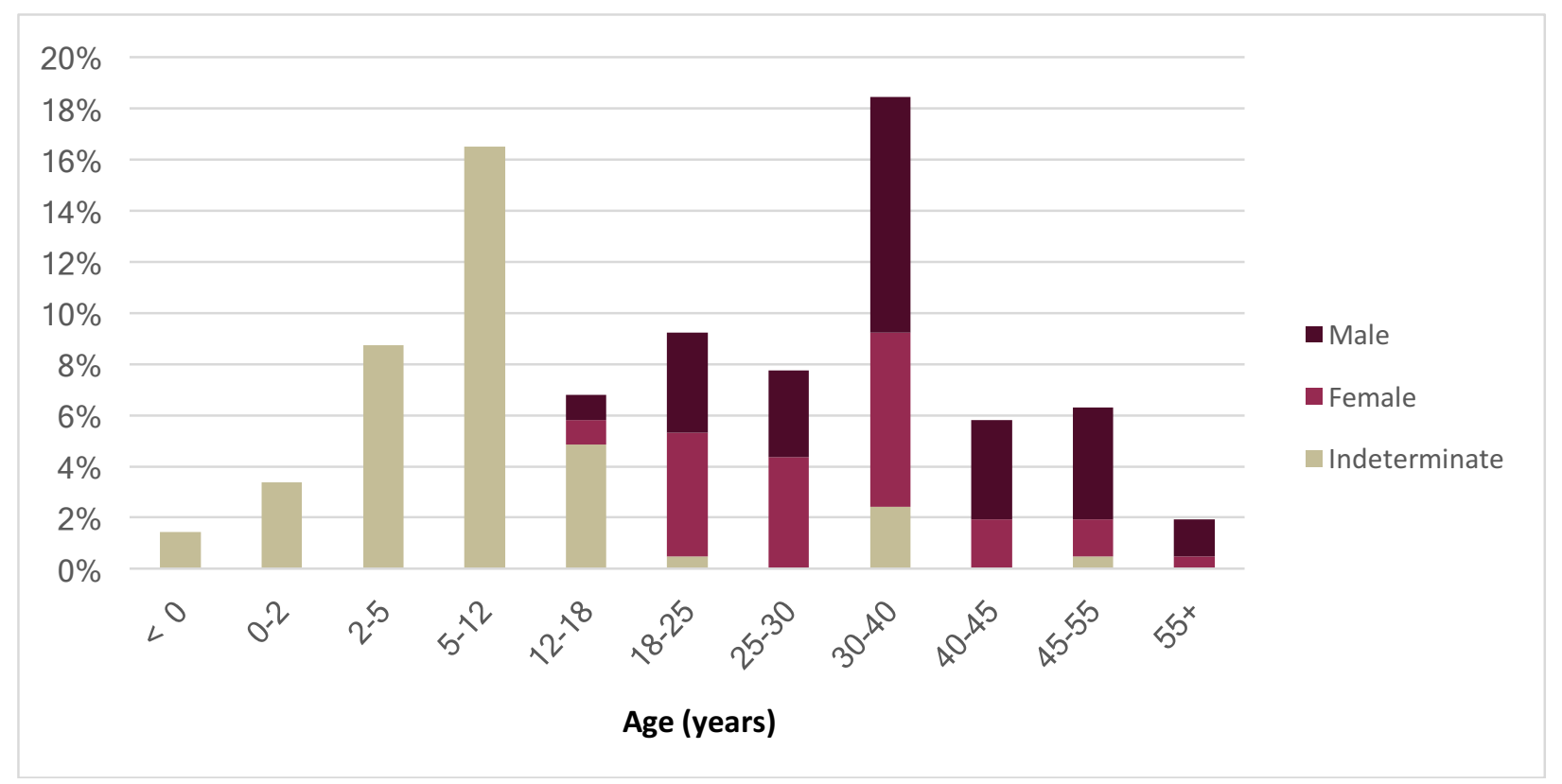

Figure 6. Age- and sex-specific mortality for the Black Church skeletal assemblage.

\subsubsection{Stature}

Measurement of the maximum length of the bones of 98 individuals ( $\mathrm{N}=37$ females and $\mathrm{N}=61$ males) allowed the estimation of their stature. If calculated on the left femur, average female stature was $157.4 \mathrm{~cm}$, with values ranging between a minimum of $146.9 \mathrm{~cm}$ and a maximum of $173.4 \mathrm{~cm}$, while male stature was on average $170.9 \mathrm{~cm}$ and measured $152.5 \mathrm{~cm}$ at its lowest, and $188.4 \mathrm{~cm}$ at its highest. 


\subsubsection{Skeletal changes}

Skeletal lesions of different aetiology were observed on more than $60 \%(\mathrm{~N}=135)$ of the analysed population (Table I). The majority of them were adults $(74.8 \%, \mathrm{~N}=101)$, although quite a few of them were juveniles $(25.2 \%, \mathrm{~N}=34$ ). Furthermore, males outnumbered females (respectively $40.7 \%, \mathrm{~N}=55$ and $29.6 \%, N=40)$. Dental lesions were the most prevalent $(60.7 \%, N=82)$ on both sexes and on adults. Degenerative joint disease was observed on $36.3 \%$ of individuals $(\mathrm{N}=49)$, activity markers on $25.9 \%$ $(\mathrm{N}=35)$ and traumatic lesions on $19.2 \%(\mathrm{~N}=26)$ of analysed individuals, mostly adult males. Infectious disease $(17.7 \%, \mathrm{~N}=24)$ and metabolic conditions $(16.3 \%, \mathrm{~N}=22)$ were mostly observed on females and juveniles. Miscellaneous lesions, congenital conditions, DISH (Diffuse Idiopathic Skeletal Hyperostosis, or Forestier's disease, causing ankylosis of the spine) and tumors represented a small percentage (respectively $9.6 \%, \mathrm{~N}=13,6.6 \%, \mathrm{~N}=9 ; 2.2 \%, \mathrm{~N}=2$ and $0.7 \%, \mathrm{~N}=1$ ) of the pathological sample.

Table I. Skeletal changes observed on the Black Church cemetery skeletal assemblage. Percentages were calculated in relation to the total of individuals included in the pathological sample $(N=139)$, and in relation to the whole population $(N=206)$. The total of $M N I$ is not equal to the total of the pathological sample given that some individuals exhibited more than one condition.

\begin{tabular}{|l|c|c|c|}
\hline \multicolumn{1}{|c|}{ Skeletal change } & MNI* & \% Pathological sample & \% Population \\
\hline Dental lesions & 82 & $60.74 \%$ & $39.81 \%$ \\
\hline $\begin{array}{l}\text { Degenerative joint } \\
\text { disease }\end{array}$ & 49 & $36.30 \%$ & $23.79 \%$ \\
\hline 'Activity' markers & 35 & $25.93 \%$ & $16.99 \%$ \\
\hline Trauma & 26 & $19.26 \%$ & $12.62 \%$ \\
\hline Infection & 24 & $17.78 \%$ & $11.65 \%$ \\
\hline Metabolic conditions & 22 & $16.30 \%$ & $10.68 \%$ \\
\hline Miscellaneous & 13 & $9.63 \%$ & $6.31 \%$ \\
\hline Congenital & 9 & $6.67 \%$ & $4.37 \%$ \\
\hline DISH & 3 & $2.22 \%$ & $1.46 \%$ \\
\hline Tumors & 1 & $0.74 \%$ & $0.49 \%$ \\
\hline
\end{tabular}

*MNI = Minimum Number of Individuals

\section{BIOCULTURAL APPROACHES TO THE ARCHAEOLOGICAL CONTEXT}

Multidisciplinary sources of evidence collected for this study have provided a new perspective on aspects of the life-style of the population from Braşov, statistically represented by the analyzed group of individuals, over a period of several centuries. Although significantly limited by a lack of funds, the main objectives of this pilot project were successfully achieved by revealing important links between the results of the bioarchaeological analysis and evidence from other disciplines. This approach, and the collaboration between scholars from the humanities and sciences, has been increasingly supported and promoted by recent scholarship across disciplines [Izdebski et al. 2015]. 


\subsection{The archaeological and historical context}

The preliminary post-excavation analysis has already provided invaluable data about the nature of the Saxon community's funerary customs and about their development throughout most of the city's existence. The study of graves from a stratigraphic perspective, in correlation with the earthen deposits and with other features and objects (buildings, ruins, modern infrastructure, artefacts), has offered crucial elements in pinpointing and establishing chronological frames. Additionally, the graves also proved to be important in interpreting the site; in fact, they were often decisive in establishing its chronology.

Several renowned personalities have written about Braşov and its inhabitants. In 1550, Georg Reicherstorffer described Braşov as an architecturally and culturally attractive town divided into three suburbs inhabited by communities of Hungarians, Saxons and Bulgarians, while Romanians and other small groups of Saxons and Hungarians dwelled outside its walls [Murgescu 2001]. Social and economic diversity was striking, and local peasants, mainly of Romanian-Slavic origin, were pushed to the periphery of the settlement by the privileged newcomers [Pop 2003].

In the sixteenth century, the French Magistrate Pierre Lescalopier and the Ottoman traveller Evliyá Çelebi also travelled through Braşov and praised the city for its high level of civilization and rich trading markets [Alexandrescu-Dersca Bulgaru and Mehmet 1976]. At the end of the nineteenth century, the Englishman Charles Boner dedicated a whole chapter of his book of travels through Transylvania to the description of the city, providing a date between 1385 and 1425 for the Black Church's construction and adding a colorful description of the local population [Boner 1865].

\subsection{Population profile}

It is legitimate to think that the majority of individuals recovered from the Black Church cemetery were Saxons, given that the Saxon community was the most represented in the area within the city walls, where the more privileged newcomers dwelled, and where members of different communities were quite preoccupied in keeping their own identity. In fact, written sources and archaeological and osteological evidence all seem to point towards a somewhat segregated community never or rarely allowing intermarriage, and an urban space with clearly defined social spaces.

Most children died between five and twelve years of age, while adults died between thirty and forty years of age. This finding is striking, although low life-expectancy (the average number of years a person is expected to live), and higher mortality rates for younger individuals (the proportion of individuals dying in a specific interval of time), were outcomes in line with studies on past populations [Chamberlain 2006], and in particular those from the medieval-modern period [Ahlström 2011]. Therefore, such mortality rates might have been the consequence of 1) a sample bias, or 2) the impact of external factors (e.g. famine, climatic shifts, or epidemics [cf. Cernovodeanu and Binder 1993]). 

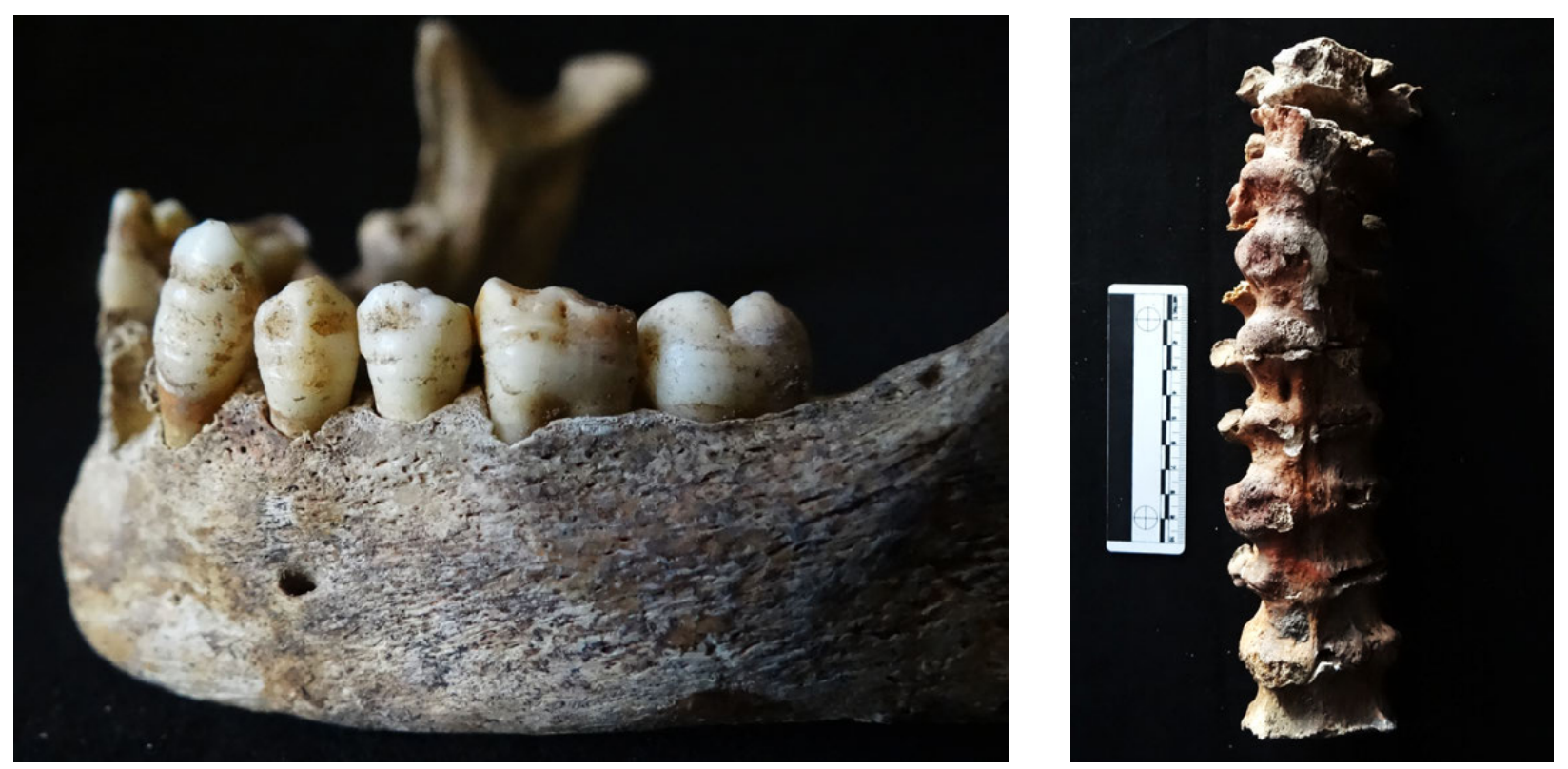

Figure 7. Left: Mandible showing several linear hypoplastic defects of the dental enamel, older child (5-12 years). Right: "Candle-wax" formation (typical of DISH) on the right anterior view of thoracic and lumbar vertebrae of a male aged over 50 years (photo: Annamaria Diana).

\section{3 "Health" and disease}

Despite their relatively "prosperous" environment, the majority of individuals from Braşov were not spared high rates of ill-health. Adults over 35 years of age were the age category showing higher morbidity levels. Furthermore, 10\% of individuals displaying pathological lesions exhibited evidence of physiological stress and malnourishment, e.g. porosity of the orbital roof (cribra orbitalia) and defects of the dental enamel (enamel hypoplasia) (figure 7, left).

Furthermore, data from the osteological analysis, integrated with archaeological data, historical and written sources, allowed the observation of biocultural patterns in specific case-studies, indicating:

1) favorable living conditions for individuals affected by congenital and/or crippling diseases, reaching adulthood despite their complete dependence on others for survival [Diana 2015];

2) gender-related morbidity patterns possibly linked with social status and activity-i.e., men and women presented different disease-specific profiles;

3) the presence of pathological conditions possibly caused by or triggered by "high status" dietary habits - a high prevalence of dental cavities, plaque and antemortem tooth loss, and the identification of DISH on three male individuals (figure 7, right). The latter condition, in particular, has been linked to obesity and type II diabetes and has been frequently observed among skeletal remains from monastic sites; its presence, however, should not be conclusive in considering the affected individual as necessarily of high social status [Rogers and Waldron 2001]. 
Finally, the appearance of bones showing charring, fissuring and discoloration at specific anatomical locations shown in forensic case studies of fire victims [e.g. Buikstra and Swegle 1989] might be considered as evidence of victims of historically recorded fires. This possibility, however, is to be further investigated.

It is too early to draw final conclusions about morbidity patterns observed on a relatively small group of individuals, given that the herein presented results may (and most likely will) change when the whole assemblage is analysed. However, possible general patterns have been identified, and specific lines of enquiry for a better understanding of the influence of social, cultural and environmental factors in the shaping of the demographic and pathological profile of this population have been highlighted.

\section{CONCLUSIONS}

Observing the development and use of a funerary site for over six centuries by the same, stable community is a rare opportunity in Romania. Given the substantial amount of human skeletal remains retrieved from Braşov's Black Church cemetery still awaiting post-excavation processing and analysis as well as the wealth of archaeological evidence, including human artefacts and animal bones systematically collected by the excavation team, this assemblage offers an great variety of possible research pathways.

We hope to follow up the pilot study presented here with the completion of the post-excavation analysis of all finds, which will allow:

1) the integration of multi-disciplinary sources with the bioarchaeological database;

2) comparisons with other Romanian and European medieval and post-medieval cemeteries;

3) isotopic and biomolecular analyses for a better understanding of dietary habits, migration, ancestry, and disease;

4) the interpretation of mass graves/family groups;

5) the interpretation of specific case-studies.

This study was aimed at presenting the archaeological context and the biological and socio-cultural profile of a small group of individuals from the Black Church courtyard. In order to achieve a wider perspective, data provided by osteological and archaeological sources of evidence were interpreted in the light of the historical context. As a result, a better understanding of population dynamics in this area has provided new insights on the history and anthropology of the Transylvanian city of Braşov, and has showed the enormous potential offered by further analysis of the whole assemblage.

\section{ACKNOWLEDGEMENTS}

The authors would like to thank the local Church authorities for allowing the archaeological excavation and access to the Black Church skeletal assemblage for scientific purposes, and Dan O'Meara for his helpful comments to improve this paper. 


\section{REFERENCES}

T. Ahlström, T. 2011. Life-history Theory, Past Human Populations and Climatic Perturbations. International Journal of Osteoarchaeology, 21(4), 407-419.

M. M. Alexandrescu-Dersca Bulgaru and M.A. Mehmet, editors. 1976. Călători străini despre Ţările Române. Vol. VI. Bucureşti: Editura Stiinţifică.

A. C. Aufderheide and C. Rodríguez-Martín. 1998. The Cambridge Encyclopaedia of Human Palaeopathology. Cambridge University Press.

Á. Bálint. 2009. Biserica Neagră din Brașov. Noi propuneri privind cronologia și contextul construcției. In: Ars Transsilvaniae, Cluj-Napoca, XIX, 5-18.

W. M. Bass. 2005. Human Osteology: A Field Guide and Manual. 5th ed. Missouri: Archaeological Society.

S. Black and L. Scheuer. 1996. Age Changes in the Clavicle: from the Early Neonatal Period to Skeletal Maturity. International Journal of Osteoarchaeology 6, 425-434.

C. Boner. 1865. Transylvania; Its Products and its People. London: Longmans, Green, Reader and Dyer.

S. T. Brooks and J. M. Suchey. 1990. Skeletal Age Determination Based on the Os Pubis: A Comparison of the Acsádi-Nemeskéri and Suchey-Brooks Methods. Human Evolution 5, 227-238.

D. Brothwell. 1989. The Relationship of Tooth Wear to Aging. In: M.Y. İşcan, editor. Age Markers in the Human Skeleton. Springfield, Illinois: C.C. Thomas, 306-316.

J. L. Buckberry and A. T. Chamberlain. 2002. Age Estimation from the Auricular Surface of the Ilium: a Revised Method. American Journal of Physical Anthropology 119, 231-239.

J. E. Buikstra and D. H. Ubelaker. 1994. Standards for Data Collection from Human Skeletal Remains: Proceedings of a Seminar at the Museum of Natural Hystory, Organized by Jonathon Haas. Arkansas Archaeological Survey Research Series No. 44. Fayetteville, Arkansas.

J. E. Buikstra and M. Swegle. 1989. Bone Modification Due to Burning: Experimental Evidence. In: R. Bonnichsen and M. Sorg, editors Bone Modification. Orono, Maine: University of Maine, 247-58.

P. Cernovodeanu and P. Binder. 1993. Cavalerii Apocalipsului. Calamităţile naturale din trecutul României (până la 1800). Bucureşti: Ed. Silex.

A. Chamberlain. 2006. Demography in Archaeology, Cambridge Manuals in Archaeology. Cambridge; New York: Cambridge University Press.

M. Crîngaci Țiplic. 2011. "Oaspeții germani” în sudul Transilvaniei. Istorie, arheologie și arhitectură (sec. XII-XIII). București.

A. Diana. 2015. The Demographic and Pathological Profile of a Group of Skeletal Remains from the Black Church: A Preliminary Study. In: D. Marcu Istrate (ed.) Redescoperirea trecutului medieval al Braşovului - Unearthing the Medieval Past of Braşov. Cluj Napoca: Editura Mega, 181-192.

G. Entz. 1996. Erdély építészete a 14-16 században. Kolozsvár.

S. Hillson. 2005. Teeth. 2nd ed. Cambridge Manuals in Archaeology.

M. Y. İşcan, S. R. Loth, and R. K. Wright. 1984. Metamorphosis at the Sternal Rib End: A New Method to Estimate Age at Death in White Males. American Journal of Physical Anthropology 65(2), 14756.

A. Izdebski et al. 2015. Realising Consilience: How Better Communication between Archaeologists, Historians and Natural Scientists Can Transform the Study of Past Climate Change in the Mediterranean, Quaternary Science Reviews http://dx.doi.org/ 10.1016/j.quascirev.2015.10.038 
E. Kühlbrandt. 1898 Die evangelische Stadtpfarrkirche A.B. in Kronstadt, I, Kronstadt.

E. Kühlbrandt. 1927 . Die evangelische Stadtpfarrkirche A.B. in Kronstadt, II, Kronstadt.

C. O. Lovejoy, R.S. Meindl, T. R. Pryzbeck, and R. P. Mensforth. 1985. Chronological Metamorphosis of the Auricular Surface of the Ilium. A New Method for the Determination of Adult Skeletal Age at Death. American Journal of Physical Anthropology 68, 15-28.

D. Marcu Istrate. 2007. Sibiu, Piața Huet. Monografie Arheologică, Alba Iulia.

D. Marcu Istrate, editor. 2015. Redescoperirea trecutului medieval al Brașovului: curtea Bisericii Negre/Unearthing the Medieval Past of Brașov: The Black Church Yard. Cluj Napoca.

D. Marcu Istrate, M. Constantinescu, and A. Soficaru. 2015.The Medieval Cemetery of Sibiu. Tübingen.

B. Murgescu, editor. 2001. Istoria României în texte. Bucureşti: Corint.

T. Nägler. 1992. Aşezarea saşilor în Transilvania. Bucureşti.

P. Niedermaier. 2002. Städtebau im Mittelalter. Siebenbürgen, Banat und Kreischgebiet (1242-1347). Köln.

P. Niedermaier. 2004. Städtebau im Mittelalter. Siebenbürgen, Banat und Kreischgebiet (1348-1541). Köln.

G. Nussbächer. 2008. Ghid prin Biserica Neagră din Brașov. Brașov.

D. J. Ortner. 2003. Identification of Pathological Conditions in Human Skeletal Remains. Second ed. San Diego, CA: Academic Press.

I.-A. Pop. 2003. Transilvania în secolul al XIV-lea şi prima jumătate a secolului al XV-lea (cca 13001456). In: I.-A. Pop and T. Nägler, editors, Istoria Transilvaniei, vol. I (până la 1541), Centrul de Studii Transilvane.

C. Roberts and K. Manchester. 2010. The Archaeology of Disease. Stroud: The History Press.

M. Philippi. 1996. Kronstadt. Historische Betrachtungen über eine Stadt in Siebenbürgen. Bukarest.

J. Rogers and T. Waldron. 2001. DISH and the Monastic Way of Life. International Journal of Osteoarchaeology 11, 357-365.

H. Roth. 2010. Kronstadt in Siebenbürgen. Eine kleine Stadtgeschichte. Köln Weimar Wien.

M. Schaefer, S. Black, L. Scheuer. 2009. Juvenile Osteology: A Laboratory and Field Manual. Elsevier Academic Press.

T. W. Todd. 1920. Age Changes in the Pubic Bone. I. The Male White Pubis. American Journal of Physical Anthropology 3, 285-334.

M. Trotter and G. C. Gleser. 1952. Estimation of Stature from Long Bones of American Whites and Negroes. American Journal of Physical Anthropology 10, 463-514.

V. Vătășianu. 1959. Istoria artei feudale în Țările Române. București.

T. Waldron. 2009. Palaeopathology. Cambridge: University Press.

T. D. White and P. A. Folkens. 2005. The Human Bone Manual. Academic Press.

Received March 2017; revised July 2017; accepted August 2017. 